Whitlock, M. C. (2011): $\mathrm{G}_{\mathrm{ST}}$ and D do not replace $\mathrm{F}_{\mathrm{ST}}$ Mol. Ecol., 20: 1083-91.

WeIR, B. S. and C. C. Cockerham (1984): Estimating F-statistics for the analysis of population-structure. Evolution, 38: 1358-1370.

Young, A., T. BoYle and T. BRown (1996): The population genetic consequences of habitat fragmentation for plants. Trends Ecol. Evol., 11: 413-418.
YounG, A. and N. Mitchell (1994): Microclimate and vegetation edge effects in a fragmented podocarp-broadleaf forest in New Zealand. Biol. Conserv., 67: 63-72.

Yeh, F. C., R-C. Yang, T. B. J. Boyle, Z-H. Ye and J. X. MaO (1997): POPGENE, the user-friendly shareware for population genetic analysis. Molecular Biology and Biotechnology Centre, University of Alberta, Canada.

\title{
Strong Genetic Control of High Wood Specific Gravity in Young Progenies of Pinus brutia: Potential of Early Selection for Industrial Plantations
}

\author{
By K. YILdIRIM ${ }^{1)}$, H. ÖZTÜRK ${ }^{2)}$, S. SikLAR ${ }^{2)}$, O. D. BALKIz ${ }^{2)}$ and Z. KAYA ${ }^{1), *)}$
}

(Received $17^{\text {th }}$ December 2010)

\begin{abstract}
To increase quality and amount of wood production in Turkish red pine (Pinus brutia Ten.), genetic control of wood specific gravity (WSG), tracheid length and growth traits was investigated in Ceyhan $1 \mathrm{~A}$ progeny trial by evaluating 168 families originated from six clonal Turkish red pine seed orchards. Wood samples were taken by destructive sampling during the rouging of this trial at the age of seven. Differences among the 168 families for mean WSG was large (ranged from 0.35 to 0.62 ), as indicated by high individual $(0.42 \pm 0.07)$ and family mean $(0.55 \pm 0.03)$ heritabilities. Family differences and high heritabilities were also observed for all growth traits and tracheid length. Genetic correlations between WSG and growth traits were insignificant (near zero), while low and insignificant negative phenotypic correlations among the same traits were also observed. Predicted genetic gain for single trait selection at age of seven was low for WSG $(0.37 \%)$, but substantial for stem volume $(8.4 \%)$ in phenotypic seed orchards. However, the first generation clonal seed orchards consisting of the best 30 clones yielded higher genetic gains $(5.2 \%$ for WSG and $35 \%$ for stem volume). These preliminary results suggest that selection for wood characteristics and growth traits in Turkish pine could be practiced at early ages for short rotation (about 30 years) in industrial plantations.
\end{abstract}

Key words: Pinus brutia, Wood Specific Gravity, Progeny Test, Heritabilities, Genetic and Phenotypic Correlations, Genetic Gain.

1) Department of Biological Sciences, Middle East Technical University, 06531 Ankara, Turkey.

2) Forest Trees and Seeds Breeding Research Directorates, Ministry of Environment and Forestry, Ankara, Turkey.

*) Corresponding author: ZEKI KAYA. Phone: (+90) 3122105177. E-Mail: kayaz@metu.edu.tr.

\section{Introduction}

Turkish red pine (Pinus brutia Ten.) is naturally distributed in the Mediterranean and Aegean regions of Turkey (ANONYMOUS, 2006). It grows on an extremely wide range of ecological, climatic, and geographical gradients, from sea level up to an elevation of 1500 meters (FIscher et al., 2008). Total forest cover of the species is estimated to be approximately 4 million hectares, which constitutes about $50 \%$ of the coniferous and $20 \%$ of the total forest area in the country (FISCHER et al., 2008). The species is also one of the most valuable commercial trees providing both timber resources and amenities. Due to its high wood density and long, suitable wood fibers for pulp and paper production, adaptability to arid conditions, fast growth and early flowering, Turkish red pine is considered as an excellent choice for industrial plantations (GeZER and AsLAN, 1980; GEZER, 1986; UstA, 1991; ICGEN et al., 2006). Evaluation of the optimal rotation age for industrial plantations of Turkish red pine indicates that with intensive silvicultural treatments and on good sites, the optimum volume for harvesting could be achieved as early as age 27 in the species (UsTA, 1991).

In Turkey, tree breeding programs were firstly initiated by delineating seed procurement and deployment zones. Although selection of seed stands and plus trees and establishment of first generation clonal seed orchards were completed for many tree species in $1960 \mathrm{~s}$, a systematic-long term breeding plan was not available until preparation of "National Tree Breeding and Seed Production Programme (NTBP) for Turkey" (KoskI and ANTOLA, 1993). With NTBP, five main tree species, including Turkish red pine, were given the highest priority and defined as target species for intensive tree breeding studies. 


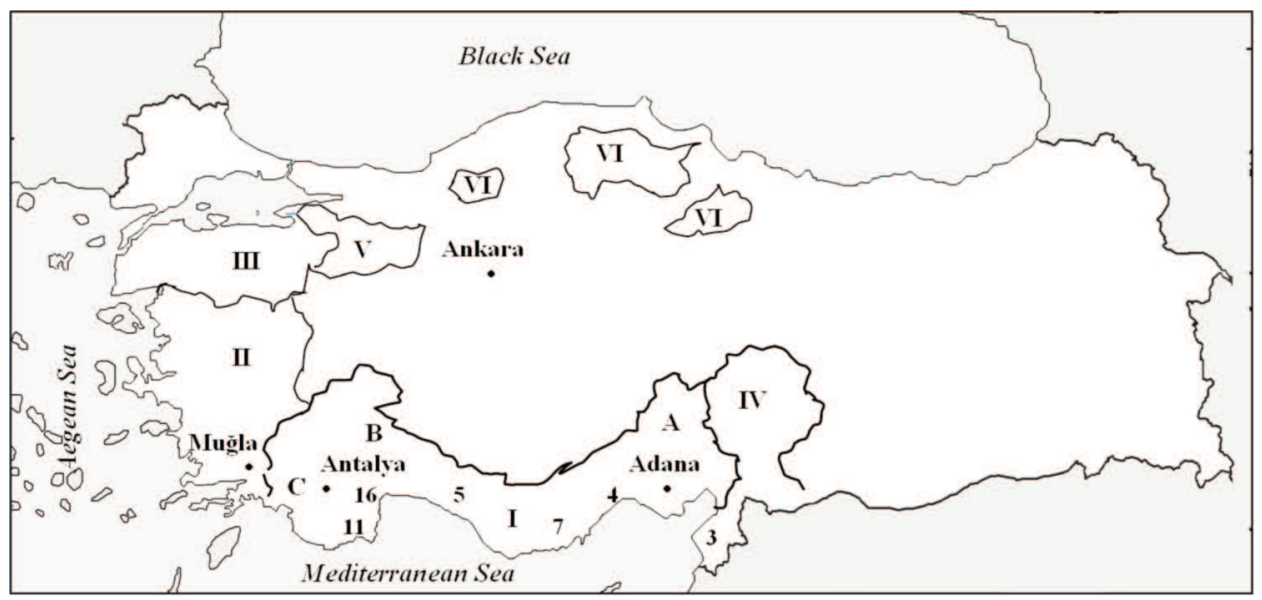

Figure 1. - Distribution and location of breeding zones for Turkish red pine (I. Mediterranean II. Aegean, III. Marmara, IV. Amanos Mountains, V. Western Anatolian and VI. Black Sea regions) and locations of low elevation breeding zone of Mediterranean region progeny trials (A; Adana-Ceyhan1A, B; Antalya-Antalya1A, C; Antalya-Fethiye1A). Numbers indicate the location of the seed orchards used in this study (3; Antakya-Uluçınar, 7; Mersin-Anamur, 4; Mersin-Silifke, 5; Antalya-Alanya, 11; Antalya-Kumluca, 16; Antalya-Kemer).

Due to the wide distribution of Turkish red pine in climatically different regions, its breeding program has been partitioned into six main breeding zones (Figure 1). In the program, up to now totally 3014 phenotypically superior plus trees have been selected from 139 high quality natural stands (20344.6 ha.) representing the species natural range. The selected plus trees have been grafted in a total of 68 seed orchards. Furthermore, in five of the six main breeding zones, progeny trials were established with seed collected from the first generation and genetically unrouged seed orchards (ICGEN et al., 2006).

Wood specific gravity (WSG) is the most widely used criterion for evaluating quality of wood and its strength properties. Wood specific gravity itself is dimensionless and defined as the ratio of the dry weight of wood substance to the weight of an equal volume of distilled water at $4^{\circ} \mathrm{C}$. Wood density, on the other hand, is the ratio of the dry weight of wood to its volume and normally expressed as kilograms per cubic meter $\left(\mathrm{kg} / \mathrm{m}^{3}\right)$ (BARBosa and FEARNSIDE, 2004). In fact, wood density and wood specific gravity are different ways of expressing the amount of actual wood substance present in a unit volume of wood. WSG was primarily used in this study, but either specific gravity or density can be calculated by knowing the other. The magnitude and direction of relationships between WSG and other related traits (growth and wood characteristics) directly influence the genetic gain, and the quality of wood obtained from intensively managed plantations (ZHANG and JIANG, 1998; LoUZADA et al., 2002). Therefore, WSG was selected as an ideal trait for genetic improvement in NTBP (Koski and ANTOLA, 1993). Although WSG is commonly referred to as an individual trait, it is actually a composite of several wood properties such as chemical content of the wood, tracheid length, cell wall thickness, cell diameter and latewood to earlywood ratio. These properties contribute to the overall specific gravity of wood. Thus, they may or may not be genetically independent of each other (KAYA et al., 2003).

There is surprisingly very little published information dealing with genetic control of WSG and its relation to other growth traits in Turkish red pine (KAYA et al., 2008). Previous studies have mainly dealt with the genetic control of the growth traits (IŞIK and KARA, 1997; KAYA and IşıK, 1997; IŞıK and IşıK, 1999; ÖZTÜRK et al., 2004). In the current study, the main objective was to investigate genetic parameters concerning wood specific gravity of young Turkish red pine progenies and its genetic relation with growth traits (height, diameter, stem volume) and tracheid length. Furthermore, it was aimed to evaluate the potential of early selection in WSG and volume for industrial plantation with short rotation.

\section{Material and Methods}

\section{Field trial}

Due to its wide distribution in different ecological regions, the Turkish red pine tree breeding program has been partitioned into six main breeding zones based on major climatic and geographical gradients and early genetic test results. According to different elevational ranges, these breeding zones were further divided into subzones. Each subzone was considered as a separate breeding unit. One of the these zones, which is the subject of this study, is a low elevation breeding subzone (0-400 m) of Mediterranean Main Breeding Zone (Figure 1). To implement the Turkish Red Pine Breeding Program in the Low-Elevation Mediterranean Breeding subzone, a total of 168 phenotypically superior-plus trees were selected from natural stands and grafted into six seed orchards (Table 1). To test the 168 clones in these orchards, progeny trials were established in 1998 at three sites (Fethiye, Antalya and Ceyhan in the Mediterranean Low Elevation Zone; Figure 1). The trials 
were coded as; Fethiye1A, Antalya1A and Ceyhan1A. All the details related to those progeny trials were provided in ÖZTÜRK et al. (2004).

Wood samples, used in this study, were collected from 168 open-pollinated half-sib families of Turkish red pine from the Ceyhan1A progeny trial established in Adana province (Figure 1). The Ceyhan progeny trial was established with "R" (sets-in-replicates) type experimental design (Schutz and Cockerham, 1966). In this design, four sets were established and then seven blocks were placed into each set. Forty-two families were randomly distributed into each set (Table 1). With this design, each family in a set was represented with 28 ( 7 block $x$ 4 trees in a row plot) trees. Additionally, seedlings from 6 families which were originated from six different seedstands representing the Mediterranean region were included into the Ceyhan progeny trial as check-lot materials. In total, 5376 trees were tested in the progeny trial (48 family/set $\mathrm{x} 4$ trees/family/block/set $\mathrm{x}$ $7 \mathrm{blocks} / \mathrm{set} \mathrm{x} 4$ sets $=5376)$.

\section{Sampling for WSG and wood quality measurements}

The Ceyhan progeny trial was established on agricultural land and initial spacing between trees was $2 \mathrm{~m} \times 3 \mathrm{~m}$. At the age of seven years, this spacing became inadequate for development of the trees. Therefore, a systematic thinning program was initiated in 2005 by removing first and third trees in each four-row plot. Determination of wood characteristics of Turkish Red Pine was carried out using wood samples obtained from the trees removed during the thinning of this trial at age seven. Before removal, the diameter and height of trees were measured and the north facing side was marked at the breast height. Half of the total number of trees were removed from the trial (48 family/set $\mathrm{x}$ 2 trees/family/block/set x 7 blocks/set x4 sets $=2688$ ).

After felling, a $10 \mathrm{~cm}$ thick wood disk was cut from each tree at $1.30 \mathrm{~m}$ above ground (at the breast height).
Although ZOBEL and TALBERT (1984) reported a high correlation between breast height samples and whole-tree density for many conifers, nevertheless, WSG variation at different heights in the stem was also observed in some tree species (ZoBEL and VAN BUIJTENEN, 1989). Therefore, to have a better representation of WSG of the whole tree, $10 \mathrm{~cm}$ disks were also cut at three different stem heights $(0,1.30$ and $4 \mathrm{~m}$ above ground) from a randomly selected subset of 192 trees (48 families). The bark of all sampled wood disks was removed to prevent decomposition. Then, the wood discs were air dried and stored at the room temperature until being prepared for WSG measurement.

\section{Determination of wood specific gravity (WSG),}

Calculation of ring width-weighted WSG was done by volumetric method, where the dry weight of a piece of wood is divided by its volume (WILLIAMSON and WIEAMANN, 2010). Wood samples were cut from the south and north sides of the wood disks into blocks of $2 \times 2 \times 3 \mathrm{~cm}$ dimensions using a buzz saw. Wood samples taken from the wood disks at the base of the trees included last four annual rings (representing the ages of 4, 5, 6 and 7) while the top $(4 \mathrm{~m})$ samples contained the last two annual rings( the ages of 6 and 7). At breast height, the samples included only 3 rings (5, 6 and 7 ages). To approximate the conditions of natural saturation, each wood sample was soaked in a water bath filled with distilled water and kept in the bath for two days until a constant weight of samples was obtained. Saturated volumes of samples were determined by the water displacement method. Then, they were oven-dried at $102 \pm 3^{\circ} \mathrm{C}$ for 48 hours until a constant dry-weight was obtained. At the end, samples were weighed again to obtain oven dry-weight of wood at $0 \%$ moisture content. The WSG values of wood samples were calculated by computing the ratio of the dry mass of the wood to its respective saturated volume (BARBOSA and FEARNSIDE, 2004).

Table 1. - Origins of the families (clones) tested in first series Turkish red pine progeny trial of Low Elevation Breeding Zone (0-400 m) of the Mediterranean Ecoregion and their distribution to the sets in Ceyhan 1A progeny trial.

\begin{tabular}{|c|c|c|c|c|c|}
\hline \multirow{3}{*}{$\begin{array}{c}\text { National Registration } \\
\text { Number of The Seed } \\
\text { Orchards }\end{array}$} & \multicolumn{4}{|c|}{ Ceyhan 1A Progeny Trail } & \multirow{3}{*}{$\begin{array}{c}\text { Number of } \\
\text { Clones Found in } \\
\text { Seed Orchards }\end{array}$} \\
\hline & \multicolumn{4}{|c|}{ Sets } & \\
\hline & 1 & 2 & 3 & 4 & \\
\hline $\begin{array}{ll}3 & \text { (Antakya-Uluçınar) }\end{array}$ & 14 & 10 & & & 24 \\
\hline 7 (Mersin-Anamur) & 14 & 16 & & & 30 \\
\hline $\begin{array}{ll}4 & \text { (Mersin-Silifke) }\end{array}$ & 14 & 16 & 5 & & 35 \\
\hline 5 (Antalya-Alanya) & & & 15 & 14 & 29 \\
\hline 11 (Antalya-Kumluca) & & & 11 & 14 & 25 \\
\hline 16 (Antalya Kemer) & & & 11 & 14 & 25 \\
\hline TOTAL & 42 & 42 & 42 & 42 & 168 \\
\hline Checklots & 6 & 6 & 6 & 6 & 6 \\
\hline
\end{tabular}


Determination of early and late wood proportions and tracheid length

To investigate the relationship between WSG and latewood proportion, $2 \mathrm{~cm}$-disks were sampled from the $10 \mathrm{~cm}$ breast height disks removed from each tree. The $2 \mathrm{~cm}$ disks were sanded with an orbital sander to obtain a clear surface. Then, each disk's picture was taken with a morphometric light microscope. These images were subjected to a morphometric light microscope analysis system (Leica Model MZ16, Germany) to measure annual ring width and late wood width. The ring boundaries in Turkish red pine have high color contrast so early and latewood could be distinguished using this color change. This color contrast differentiation was also associated with changes in tracheid-lumen diameter from earlywood to latewood. For this purpose, very thin slices were taken from the $2 \mathrm{~cm}$ wood disks with a microtome and changes between early to late wood examined with a light microscope. When the changes of tracheid-lumen diameters reached a two fold increase from early to late wood, this zone was accepted as the transition from early to late wood (GULLER, 2006). Latewood percentages were calculated based on the latewood widths of the growth rings divided by the total width of the rings.

Additionally, tracheid lengths also measured to investigate its relationships with WSG. For this purpose, all families used to estimate WSG in the trial were firstly grouped into three categories based on the magnitude of the WSG values such as low, moderate and high. Then, 20 families were randomly selected from each group. After taking the wood samples for WSG determination, the remaining parts of the wood disks from breast height of the trees were utilized for tracheid length measurement. First, annual rings representing ages between three to six was separated from the wood disks and each ring was cut into pieces as the size of matchsticks. Then, they were macerated in a boiling mixture of acetic acid:hydrogen peroxide $(1: 1 \mathrm{v} / \mathrm{v})$. Furthermore, the tracheid suspension was fixed to microscope slides with a methyl blue solution that is used to dye tracheids (GRAY, 1965). By using a light microscope (LEICA Model MZ16, Germany), the lengths of 30 undamaged trachei$\mathrm{ds}$, coming from both early and latewood, were measured for each tree of a family (14 trees per family x 20 families per WSG category x $3 \mathrm{WSG}$ categories $=840$ trees) to estimate an average tracheid length.

\section{Statistical analysis}

Analysis of variance (ANOVA) and Multivariate Analysis of Variance (MANOVA) for the studied traits were carried out by using a Proc Mixed Procedure of SAS (SAS INST, 2004). The following linear statistical model was used to estimate the family component of total variance in the traits and covariance components between traits.

$$
Y_{i j k l}=\mu+S_{i}+B_{j(i)}+F_{k(i)}+F B_{j k(i)}+e_{i j k l}
$$

(Equation 1)

where, $Y_{i j k l}$ : Observed value of $l^{\text {th }}$ tree in the $i^{\text {th }}$ set, $j^{\text {th }}$ block, $k^{\text {th }}$ family. $\mu$ : Experimental mean; $S_{i}$ : Environmental effect of $i^{\text {th }}$ set, $i=1,2,3,4 ; B_{j(i)}$ : Effect of $j^{\text {th }}$ block in the $i^{\text {th }}$ set, $\mathrm{j}=1,2, \ldots, \mathrm{bi} ; F_{k(i)}$ : Effect of $k^{\text {th }}$ family in the $i^{\text {th }}$ set, $\mathrm{k}=1,2, \ldots, \mathrm{fi} ; F B_{j k(i)}$ : Family-block interaction; $e_{i j k l}$ : Experimental error.

Individual heritabilities $\left(h^{2}\right)$ were calculated with the following formula (LYNCH and WALSH, 1998).

$$
h_{i}^{2}=\frac{\sigma_{\mathrm{a}}^{2}}{\sigma_{\mathrm{f}}^{2}+\sigma_{\mathrm{fb}}{ }^{2}+\sigma_{\mathrm{e}}{ }^{2}}
$$

(Equation 2)

where, $\sigma_{f}^{2}$ : family variance, $\sigma_{f b}^{2}$ : Family-Block interaction, $\sigma_{e}^{2}$ : Error variance and $\sigma_{a}^{2}$ : Additive genetic variance $\left(4 \sigma_{f}^{2}\right)$.

Family heritabilities $\left(h_{f}^{2}\right)$ were calculated by using the following equations (LYNCH and WALSH, 1998).

$$
h_{f}^{2}=\frac{\sigma_{\mathrm{f}}^{2}}{\left[\sigma_{\mathrm{f}}^{2}+\left(\sigma_{\mathrm{fb}}^{2} \mathrm{c}_{2} / \mathrm{c}_{1}\right)+\left(\sigma_{\mathrm{e}}^{2} / \mathrm{c}_{1}\right)\right]}
$$

(Equation 3)

where, $\sigma_{f}^{2}$ : Family Variance, $\sigma_{f b}^{2}$ : Family-Block Interaction, $\sigma_{e}^{2}$ : Error Variance. $\mathrm{C}_{1}$ and $\mathrm{C}_{2}$ are the coefficients for family variance and block-family interaction variance, respectively (SoRENSEN and WHITE, 1988). $\mathrm{C}_{1}$ and $\mathrm{C}_{2}$ coefficients were determined by equating the observed mean squares with the TYPE III expected mean squares which were calculated by the Proc GLM of SAS (SAS INST, 2004).

Standard errors of both family and individual heritability were calculated according to the Delta model as described by LYNCH and WALSH (1998). Analyses of covariance between traits were carried out to estimate covariance components, which are used to determine the genetic and phenotypic correlations. Variance components were estimated by using PROC VARCOMP REML option of SAS (SAS INST, 2004). Genetic correlations ( $\mathrm{R} g(\mathrm{x}, \mathrm{y})$ ) were calculated by the following equation (FALCONER, 1981; KAYA et al., 1989).

$$
\mathbf{R}_{\mathrm{g}(\mathrm{x}, \mathrm{y})}=\frac{\operatorname{Cov}_{f(x, y)}}{\sqrt{\sigma_{f x}^{2} \cdot \sigma_{f y}^{2}}}
$$

(Equation 4)

where $R_{g(x, y)}$ is estimated genetic correlation between traits $x$ and $y, \sigma_{f x}^{2}$ is estimated family variance components for trait $x, \sigma_{f y}^{2}$ is estimated family variance for trait $y$ and $\operatorname{Cov}_{f(x, y)}$ is estimated genetic covariance between traits $x$ and $y$. The phenotypic correlations between traits $x$ and $y$ were calculated as described in KAYA et al. (1989). Standard errors of genetic and phenotypic correlations were calculated according to FALCONER and MACKAY (1996) and KAYA et al. (1989).

\section{Estimation of Breeding Values (BV) and Genetic Gains}

To bring the results of genetic trials into an application, it is often useful to express the results in terms of response to selection, or gain from selection. In this sense, the calculation of breeding values (BV) is attractive because it allows breeders flexibility to choose parents with high BV for a combination of traits (YANCHUK and KISS, 1993). Breeding values for each family in the present study were calculated via the best linear unbiased predictors method (BLUPs) using Proc Mixed procedure with restricted maximum likelihood (REML) option in SAS (SAS INST., 2004). 
As genetic gains from selection or breeding programs are determined by a comparison with unimproved materials, combined checklots were treated and taken as the baseline in the prediction of breeding values of families in this trial. However, the average of estimated breeding values, calculated by BLUP, is equal to zero. Therefore, it is not possible to compare tested material with the checklots. To overcome this problem, absolute breeding values (ABV) were calculated by adding the general mean of the traits to the breeding values. Then, genetic gains were calculated as described in the sections below.

Genetic gain from rouged phenotypic seed orchard $\left(\Delta G_{r s o}\right)$ : In order to increase genetic gain in breeding studies, seed orchards can be subjected to a genetic rouging by leaving certain number of clone in the orchards. Genetic gain from this type rouged seed orchards were calculated with the following formula;

$$
\Delta G r s o=\frac{\left(\mathrm{BV}_{\mathrm{rf}}-\mathrm{BV}_{\mathrm{C}}\right)}{\mathrm{ABV}_{\mathrm{C}}} .100
$$

(Equation 5)

Where $B V_{r f}$ : The average breeding value estimated from the top 20 families that are left in each seed orchard, $B V_{c}$ : Average breeding value of checklots and $A B V_{c}$ : Average absolute breeding value of checklots.

Genetic gain from clonal seed orchards $\left(\Delta G_{g s o}\right)$ : Establishment of a clonal seed orchard containing grafts from clones having the highest breeding values is the best way of maximizing the genetic gain in breeding programs. Genetic gain obtained from these orchards was calculated by the following formula;

$$
\Delta \text { Ggso }=\frac{\left(\mathrm{BV}_{\mathrm{b}}-\mathrm{BV}_{\mathrm{C}}\right)}{\mathrm{ABV}_{\mathrm{C}}} .100
$$

(Equation 6)

Where $B V_{b}$ : The average breeding value estimated from the top 30 clones with the highest breeding values from all the seed orchards. The other parameters are the same as described in equation 5 .

\section{Results and Discussion}

\section{Progeny test means for Growth, WSG and Tracheid Length Traits}

Average family height, diameter and volume at age 7 were $685.2 \mathrm{~cm}$ (range: $322-1014 \mathrm{~cm}$ ), $11.95 \mathrm{~cm}$ (range: $5.78-19 \mathrm{~cm}$ ) and $43.3 \mathrm{dm}^{3}$ (range: $8.8-113 \mathrm{dm}^{3}$ ), respectively. The average annual growth increments for height $(97 \mathrm{~cm})$, diameter $(1.71 \mathrm{~cm})$ and volume $\left(6.9 \mathrm{dm}^{3}\right)$ indicated that the species has a high growth rate. Although these results were based on only one progeny trial, established in an agricultural area, the estimated high type B genetic correlations among progeny test sites including this series of progeny trials (Ceyhan1A) ÖZTÜRK et al. (2008) suggest that the best families at this site are likely to be the best one at other sites (Fethiye1A and Antalya1A). This is further supported by the strong positive genetic correlations $(0.88)$ between family performances for height at ages 4 and 8 based on the data from three other test sites with the same families (ÖzTüRK et al., 2008).

Differences in WSG values for wood samples taken from both the south and north sides of the wood-disks were found to be statistically insignificant at $P<0.01$. Therefore, all the other analyses were done and presented using the average WSG values of these two type samples. The analysis of WSG results indicated that Turkish red pine has quite superior wood with 0.438 WSG, ranging from 0.350 to 0.620 , at age seven. Despite the lack of knowledge about transition zone from juvenile to mature in literature for Turkish red pine, other studies indicate that the number of rings from tree center will determine whether or not mature wood is formed. This transition zone was found to be about 15-20 rings in Scots pine (FRIES and ERICSSON, 2009), 5-7 rings in $P$. caribaea (Oluwadare, 2007), 8-9 rings in $P$. radiata (ZAMUDIO et al., 2002) and 6-8 rings in P. elliottii (Hodge and Purnell, 1993). Our samples in this study include only 7 rings, therefore, we may conclude that our results mostly pertain to juvenile wood which is characterized by low WSG, and short tracheid length. With maturation of the wood, WSG or density will attain higher values than the estimated average WSG of 0.438 . The findings of GöKSEL and ÖZDEN (1993) support this prediction and indicate that whole disk WSG values increased from 0.433 at the age of 12 to 0.492 at age of 36 in Turkish red pine. The other studies on WSG values reported similar results such as a WSG of 0.465 for 38 year old (RAYMOND et al., 2004) and 0.507 (GÜRBOY, 2007) for 80 year old Turkish red pine trees.

The age of transition from juvenile to mature wood was mostly determined by assessing the number of growth rings from the pith to bark with respect to significant changes for an important wood property such as WSG, tracheid length or latewood-earlywood proportion (JAYAICKKRAMA et al., 1997; HANNRUP and EKBERG, 1998; ZAMUdio et al., 2002; FrIES and ERICSSON, 2009). In the current study, tracheid length measurements for different annual rings indicated an increase from pith to bark, however, significant increase in tracheid length were observed only at age six $(2.15 \mathrm{~mm})$. There were no significant differences in average tracheid lengths among the other ages (1.83, 187 and $1.89 \mathrm{~mm}$ for the ages 3, 4 and 5, respectively). ZOBEL and TALBERT (1984) summarized that tracheid length is commonly less than $2 \mathrm{~mm}$ in juvenile wood and varies between 2.5 to $5.5 \mathrm{~mm}$ in mature wood. GÜRBOY (2007) investigated fiber morphology of Turkish red pine at different ages and found an increase from $2.3 \mathrm{~mm}$ at ages $1-20$ to $3.3 \mathrm{~mm}$ at ages 80-100. Therefore, significant change in the tracheid length at age six in this study could possibly be explained by initiation of transition from juvenile to mature wood.

It has been reported in many studies that WSG varies greatly with height in the stem (KoGA and ZHANG, 2004; ZHANG and JIANG, 1998). While juvenile wood exists in the form of an inner cylinder at the center of the bole, mature wood is mostly produced at the base of the tree as an extension of this cylinder (ZOBEL and VAN BUIJTENEN, 1989). The result is that top logs consist mainly of juvenile wood which has low specific gravity, whereas the butt log of the same tree has more mature wood with a higher specific gravity (ZOBEL and TALBERT, 1984). Vertical change in WSG along the stem in the current study correspond well this variation from base to 
the top. The results indicated that average family WSG decreased abruptly above the base and then remained relatively uniform in the upper part of the stem (e.g., $0.473,0.437$, and 0.430 for $0,1.30$ and $4.00 \mathrm{~m}$ levels of stem height, respectively). These WSG differences between breast height and top samples were not significant at $P<0.01$ level. The differences in WSG along vertical positions of stems could possibly be explained with the initiation of transition from juvenile to mature wood.

HANNRUP et al. (2001) emphasized that size of wood cells and the proportion of latewood have the strongest correlation with WSG in wood. With multiple regression analysis, they could explain up to $73 \%$ of the variation in WSG. It is a known fact that the specific gravity of latewood could be over three times that of earlywood for a given ring. Although latewood to earlywood proportions for the annual rings are largely controlled by the growing conditions (temperature and rainfall) within each year this proportion can also be altered independently by transition from juvenile to mature wood (ZOBEL and TALBERT, 1984). Many studies indicated that from pith to outer wood, an increase in the latewood proportion is associated with transition from juvenile to mature wood (KogA and ZHANG, 2004; FRIES and ERICSON, 2009; ZAMUDIO et al., 2002). In this study, as in tracheid length measurements, a significant difference between annual rings for latewood to earlywood proportion was observed only at the age six. Latewood proportion at the age six was found to be $20 \%$, while this proportion was $9.24 \%$ and 9.15 for ages 4 and 5, respectively. This change at the age six could also be explained by transition from juvenile to mature wood when fiber length measurement and vertical change in WSG along with stem were considered. The annual rainfall in the progeny trial sites for the years of 2002, 2003 and 2004 which correspond to the ages of 4, 5 and 6 were 635,660 and $636 \mathrm{~mm}$, respectively (B. Ozturk, Personal Com., Turkish State Meteorological Services, July 1, 2011). From the precipitation data, it is doubtful that climatic conditions may have caused the increase in latewood proportion at the age of six. The apparent early-transition from juvenile to mature wood at the age 6-7 could present an advantage to breeding studies with regard to wood quality, when the rotation age of Turkish red pine in industrial plantations is being considered as early as about 30 years (UsTA, 1991).
Genetic variation in WSG, tracheid length and growth traits

Analysis of variance revealed that all evaluated growth traits, WSG and tracheid length at the age of seven varied significantly at the family level $(p<0.001)$ (Table 3). Among various characteristics studied, growth traits (stem volume, height, diameter) exhibit remarkably higher phenotypic variation (CV ranges from $15.2 \%$ to $42.4 \%$ ) than WSG (6.7\%). Tracheid length exhibited an intermediate variation $(12.1 \%)$ (Table 2). The variance component due to families was significant at $p<0.01$ for growth traits and accounted for $6 \%, 5.8 \%$, and $7.49 \%$ of the total variance for stem volume, diameter, height, respectively (Table 3). Although WSG and tracheid length exhibit less variation than the growth traits, the family component of the variation was significant and accounted for $10 \%$ of the total variance for both traits. Significant family differences for WSG were also reported in other pine species such as loblolly pine (JAYAiCKKrama et al., 1997) Ponderosa pine (KocH and FIns, 2000) and Pinus nigra (KAYA et al., 2003).

\section{Heritabilities}

The heritability estimates for WSG indicated that WSG is under strong genetic control in Turkish red pine, with an individual heritability of $0.42( \pm 0.07)$ and family heritability of $0.58( \pm 0.05)$ (Table 3$)$. These heritability estimates of WSG for Turkish red pine are comparable to those reported for other conifers (ZOBEL and TALBERT, 1984). Several studies (NiCHOLLS et al., 1980; TALBERT et al., 1983; ZoBEL and JETT, 1995) reported that individual heritabilities of WSG in pine species range from 0.4 to 0.70 for juvenile wood. Tracheid length also exhibited a strong heritability in this study. Individual and family heritabilties were found to be $0.42 \pm 0.12$ and $0.59 \pm 0.08$, respectively. Reported heritability estimates varied greatly for tracheid length in other species (HANNRUP and EKBERG, 1998; HANNRUP et al., 2001; FRIES and ERICSON, 2006).

Individual heritabilities $\left(h_{i}^{2}\right)$ for height, diameter and stem volume at age 7 were estimated as $0.55( \pm 0.09)$, $0.40( \pm 0.08)$ and $0.40( \pm 0.08)$, respectively. Family heritabilities for the same traits were also high and estimated as 0.64 for height, 0.56 for diameter and 0.58 for volume at age 7 . Individual heritability estimates for growth traits were reported to be low, ranging from 0.15

Table 2. - Means, standard deviations (SDEV), ranges and coefficients of variation (CV\%) of selected growth and wood traits for 168 families.

\begin{tabular}{|c|c|c|c|c|c|}
\hline & Mean & SDEV & $\mathrm{CV}(\%)$ & $\begin{array}{c}\text { Minimum } \\
\text { family mean }\end{array}$ & $\begin{array}{l}\text { Maximum } \\
\text { family mean }\end{array}$ \\
\hline WSG & 0.438 & 0.03 & 6.7 & 0.35 & 0.62 \\
\hline Diameter(cm) & 11.95 & 2.39 & 20.0 & 5.78 & 19.0 \\
\hline Stem Volume $\left(\mathrm{dm}^{3}\right)$ & 43.3 & 18.4 & 42.2 & 8.8 & 113.0 \\
\hline Height at age of $7(\mathrm{~m})$ & 6.85 & 1.04 & 15.2 & 322.0 & 1014.0 \\
\hline Height at age of $4(\mathrm{~m})$ & 2.68 & 0.51 & 19.1 & 129.0 & 431.0 \\
\hline Fiber Length (mm) & 1.93 & 2.41 & 12.10 & 1.15 & 2.80 \\
\hline
\end{tabular}


Table 3. - Estimated variance components (VC), their proportion in the total variance (\%) and some genetic parameters for wood specific gravity (WSG), growth traits and fiber length of a Turkish red pine progeny trial at the age 7 .

\begin{tabular}{|c|c|c|c|c|c|c|c|c|c|c|}
\hline \multirow[t]{2}{*}{$\begin{array}{l}\text { Source of } \\
\text { variance }\end{array}$} & \multicolumn{2}{|c|}{ WSG } & \multicolumn{2}{|c|}{$\begin{array}{c}\text { Stem } \\
\text { Volume } \\
\left(\mathrm{dm}^{3}\right)\end{array}$} & \multicolumn{2}{|c|}{$\begin{array}{l}\text { Diameter } \\
(\mathrm{cm})\end{array}$} & \multicolumn{2}{|c|}{$\begin{array}{l}\text { Height } \\
(\mathrm{cm})\end{array}$} & \multicolumn{2}{|c|}{$\begin{array}{c}\text { Fiber Length } \\
\text { (mm) }\end{array}$} \\
\hline & VC & $\%$ & $\mathrm{VC}$ & $\%$ & VC & $\%$ & $\mathrm{VC}$ & $\%$ & $\mathrm{VC}$ & $\%$ \\
\hline$\overline{\sigma_{s}^{2}}$ & 0.0004 & $1.60^{\text {ns }}$ & 0.47 & $21^{* *}$ & 1.20 & $19.3^{\mathrm{xw}}$ & 2605 & $21.0^{* x}$ & 0.87 & $1.45^{\mathrm{ns}}$ \\
\hline$\sigma_{b}^{2}$ & 0.0006 & $2.00^{* * *}$ & 0.53 & $24^{* *}$ & 1.40 & $22.4^{* *}$ & 2807 & $21.7^{* * *}$ & 2.19 & $4.20^{* *}$ \\
\hline$\sigma_{f}^{2}$ & 0.0027 & $10.1^{\text {** }}$ & 0.13 & $6.0^{* *}$ & 0.36 & $5.80^{\text {** }}$ & 964.6 & $7.49^{* *}$ & 6.13 & $10.1^{* *}$ \\
\hline$\sigma_{\mathrm{fl}}^{2}$ & 0.0007 & $2.80^{\text {ns }}$ & 0.09 & $4.3^{*}$ & 0.30 & $4.90^{*}$ & 444.7 & $3.45^{* *}$ & 0.00 & $0.0^{\mathrm{ns}}$ \\
\hline$\sigma_{e}^{2}$ & 0.0272 & 83.5 & 0.98 & 44 & 2.97 & 47.6 & 5666 & 46.2 & 50.9 & 84.7 \\
\hline$\sigma_{t}^{2}$ & 0.0317 & & 2.22 & & 6.24 & & 12487 & & 60.1 & \\
\hline$\sigma_{a}^{2}$ & 0.0109 & 40.3 & 0.52 & 24 & 1.45 & 23.2 & 3858 & 30.0 & 24.5 & 40.7 \\
\hline$\sigma_{\mathrm{pi}}^{2}$ & 0.0262 & & 1.21 & & 3.64 & & 7075 & & 57.0 & \\
\hline$\sigma_{\text {pfam }}^{2}$ & 0.0044 & & 0.23 & & 0.65 & & 1499 & & 10.3 & \\
\hline $\mathbf{h}_{i}^{2} \pm \mathbf{S} . \mathbf{E}$ & $0.42+$ & 0.07 & 0.40 & .08 & 0.4 & 08 & 0.5 & 0.09 & & 0.12 \\
\hline$h^{2}+$ S.E & $0.58+$ & 0.05 & 0.58 & 0.05 & 0.5 & 0.05 & 0.64 & -0.04 & & -0.08 \\
\hline
\end{tabular}

$\sigma_{s}^{2}$ : Set variation; $\sigma_{b}^{2}$ : Block variance in the set; $\sigma_{f}^{2}$ : Family variance; $\sigma_{t}^{2}$ : Total variance; $\sigma_{a}^{2}$ : Additive genetic variance $\left(4 \sigma_{f}^{2}\right) ; \sigma_{p i}^{2}$ : Phenotypic variance; $\sigma_{p f a m}^{2}$ : Phenotypic variance of family means; $h_{i}^{2}$ : Individual heritability; $h_{f}^{2}$ : Family heritability; $S . E$ : Standard error.

${ }^{*}$ : significant at $\mathrm{p}<0.05 ;{ }^{* *}$ : significant at $\mathrm{p}<0.01 ; n s$ : non-significant.

to 0.25 for other pines (SHELBOURNE et al., 1997). Both individual and family heritability estimates in this study indicated that these traits are under strong genetic control. Family selection seems to be effective way to obtain high genetic gain for WSG and growth traits in short terms as suggested in the National Tree Breeding Program (Koski and ANTOLA, 1993). It is generally known that heritability estimates may vary considerably from one trial to another depending on the environmental variation of the trial site. However, the result of the study with the same materials (ÖzTÜRK et al., 2008) for growth traits at age 8 for all progeny trials (Fethiye1A, Antalya1A and Ceyhan1A) supported the high heritability estimates. Especially family heritabili- ty estimates from combined data from all three progeny trials were in close agreement with the estimates of this study (i.e., family heritabilities were 0.63 for height, 0.55 for diameter and 0.54 for volume at age 8).

\section{Genetic correlations between WSG and growth traits}

Genetic correlations between WSG and growth traits such as height $\left(r_{g}=-0.03\right)$ diameter $\left(r_{g}=0.00\right)$ and stem volume $\left(r_{g}=0.01\right)$ at the age 7 were found to be insignificant. On the other hand, there was a weak and negative genetic correlation between WSG and tracheid length (Table 4). After reviewing hundreds of papers dealing with the effect of growth rate on wood density, ZOBEL and van BuiJTEnen (1989) and ZoBel and JETT (1995)

Table 4. - Estimated genetic (top diagonal) and phenotypic correlations (below diagonal) between wood specific gravity (WSG) and growth traits at the age of seven. Standard errors of genetic correlations are in brackets.

\begin{tabular}{l|ccccc}
\hline \multicolumn{1}{l}{} & Diameter & Height & Stem vol. & WSG & Fiber length \\
\cline { 2 - 6 } Diameter & & 0.69 & 0.96 & 0.00 & 0.25 \\
\multirow{3}{*}{ Height } & & $(0.02)$ & $(0.003)$ & $(0.04)$ & $(0.22)$ \\
& 0.76 & & 0.86 & -0.03 & 0.37 \\
Stem vol. & & & $(0.01)$ & $(0.05)$ & $(0.20)$ \\
& 0.97 & 0.85 & & 0.01 & 0.32 \\
WSG & & & & $(0.04)$ & $(0.21)$ \\
& -0.15 & -0.11 & -0.13 & & -0.17 \\
Fiber length & & & & & $(0.24)$ \\
\hline
\end{tabular}


reported that there is either a weak positive genetic correlation between growth rate and wood density in several genera (e.g., Picea spp. and Abies spp.) or little to no meaningful genetic correlation (e.g., hard pines) between these traits. Considering the degree of genetic and phenotypic correlations between WSG and growth traits, genetic gains can be achieved by breeding for each trait independently without loss of quantity and quality production (ZHANG and JIANG (1998). Furthermore, some studies (POT et al., 2002) have reported that selection for WSG would not be expected to alter tracheid length.

However, genetic correlations between tracheid length and growth traits were positive and moderate $\left(r_{g}=0.37\right)$ (Table 4). Also, genetic correlations between growth traits were positive and quite high, as were phenotypic correlations. Thus, selection of families with high diameter growth would cause an indirect and positive selection on height growth, stem volume increment and tracheid length.

\section{Estimated Breeding Values and Genetic Gain}

The existence of strong inheritance patterns and no meaningful relationship between growth and WSG in the current study encouraged us to estimate genetic gain predictions from phenotypic and clonal seed orchards of Turkish red pine. Although most growth assessments were based on height, gains were increased when volume growth was considered (ZOBEL and TALBERT, 1984). Therefore, for genetic gain estimations instead of all growth traits, stem volume along with WSG was taken into consideration.

The mean of absolute breeding values of all families were $0.37 \%$ higher than mean value of the check-lots for WSG though this difference was found to be insignificant. Among the seed orchards, except for seed orchard\#16 (Antalya-Kemer), breeding values for WSG for the other seed orchards were above the mean breeding values of the check-lots. However, only the seed orchard's \#4 (Mersin-Silifke) yielded significantly high genetic gain (Table 5). The highest mean WSG (0.438) and genetic gain $(1.3 \%)$ were estimated in this seed orchard (Table 5). On the other hand, the mean of stem volume-breeding values shows that considerable genetic gain $(8.6 \%)$ could be obtained by means of using seeds produced from phenotypic seed orchards. Except for the seed orchard \#16 (Antalya-Kemer), which has the lowest breeding value for WSG, all the other seed orchards' breeding values were above the mean breeding value of the check-lots. From these results, it could be proposed that seeds produced from the seed orchard \#16 (AntalyaKemer) should be avoided for plantations.

In tree breeding studies, the highest genetic gains are obtained when only the best parents from each seed orchard are brought together in new seed orchards (1.5 generation orchards). In this regard, if a 1.5 generation clonal seed orchard was established with the best 30 open pollinated families from all seed orchards depending on the WSG and stem volume traits, estimated genetic gains were calculated as $5.2 \%$ and $35 \%$, respectively (Table 5)

Calculations of genetic gains based on just one trial may be considered as unreliable parameters, especially considering that this progeny trial was established on agricultural land. However, like in estimated heritability and other genetic parameters, results for growth traits from all first series progeny trials with the same materials at age 8 indicated the consistency of the results of this trial with other progeny trials (ÖZTÜRK et al., 2008). For stem volume, genetic gain was found to be $10.1 \%$ with respect to control, while a 1.5 generation seed orchard with the best 30 clone produced $30.7 \%$ genetic gain for the same trait. Similar to the results of the pre-

Table 5. - Average breeding values (ABV) of the seed orchards and genetic gains from phenotypic and clonal seed orchards.

\begin{tabular}{|c|c|c|c|c|}
\hline \multirow[b]{2}{*}{$\begin{array}{c}\text { Codes and Name of Seed } \\
\text { Orchards }\end{array}$} & \multicolumn{2}{|r|}{ WSG } & \multicolumn{2}{|c|}{ Stem Volume } \\
\hline & $\begin{array}{l}\text { Mean } \\
\text { ABV }\end{array}$ & $\begin{array}{c}\text { Genetic Gain } \\
\text { From Phenotypic } \\
\text { Seed Orchard(\%) }\end{array}$ & $\begin{array}{l}\text { Mean } \\
\text { ABV }\end{array}$ & $\begin{array}{c}\text { Genetic Gain } \\
\text { From Phenotypic } \\
\text { Seed Orchard(\%) }\end{array}$ \\
\hline \#3 (Antakya-Uluçınar) & 0.432 & $0.0^{\mathrm{ns}}$ & 39.64 & $2.5^{* * *}$ \\
\hline \#4(Mersin-Silifke) & 0.438 & $1.3 * *$ & 46.39 & $20.0 * *$ \\
\hline \#5(Antalya-Alanya) & 0.434 & $0.4^{\mathrm{ns}}$ & 45.35 & $17.3^{* *}$ \\
\hline \#7(Mersin-Anamur) & 0.435 & $0.6^{\mathrm{ns}}$ & 41.20 & $6.5^{* *}$ \\
\hline \#11(Antalya-Kumluca) & 0.437 & $1.1^{115}$ & 40.88 & $5.7 * *$ \\
\hline \#16(Antalya-Kemer) & 0.428 & $-1.0^{\mathrm{ns}}$ & 38.63 & $0.0^{\mathrm{ns}}$ \\
\hline General Mean & 0.434 & $0.37^{\mathrm{ns}}$ & 42.34 & $8.6 * *$ \\
\hline Check-lots Mean & 0.432 & & 38.67 & \\
\hline Genetic Gain From & & $5.2 * *$ & & $35^{* *}$ \\
\hline Clonal Seed Orchard $(\%)$ & & & & \\
\hline
\end{tabular}

*** significant at $\mathrm{p}<0.05 \mathrm{~ns}$; nonsignificant. 
sent study, the seed orchard\#16 (Antalya-Kemer) again had the worst performance in terms of growth traits in all other progeny trials at age 8 (ÖZTÜRK et al., 2008).

Although there are many reports in the literature dealing with genetic gains in volume growth, there are limited number of reports for genetic gain from WSG because WSG was not justified as a selection criterion for many breeding programs. The results of estimated genetic gain for WSG in this study correspond well with the results of HANNRUP et al. (1998) and STENER and HEDENBERG (2003). In the latter study, genetic gain for WSG was estimated to be approximately $2.7 \%$ for the selection of best 20 families in Pinus sylvestris. HolloWELL and PORTERFIELD (1986) suggested 8-15\% volume gain at rotation age for Pinus taeda with a single cycle of selection and roguing of $30-55 \%$ individuals in the seed orchard.

\section{Conclusion}

Although the results of this study were based on only one trial, introducing WSG as a selection trait in Turkish red pine breeding program can be justified by the results presented from other progeny trials and strong inheritance of WSG and tracheid length. High individual and family heritabilities of WSG, tracheid length and growth traits, insignificant genetic correlations between wood quality and growth traits in Turkish red pine indicate great potential to improve these traits in the future generation through genetic selection. Family selection for wood quality and growth traits could be practiced as an effective way to obtain genetic gain in the short terms, especially for short rotation-industrial plantations. However to have maximum economic value with the improvement of WSG and growth, a multi-trait selection index should be developed by giving appropriate weight to each trait according to its relative economical importance and genetic parameters. Such index selection will provide the flexibility to breeders during culling of families at later ages in the future.

\section{Acknowledgements}

This study has been funded by the The Scientific and Technological Council of Turkey (Project number\# TOVAG-1060392).

\section{References}

AnONYMous (2006): The Forest Assets (Orman varlığımız). The Republic of Turkey-The Ministry of Envriornment and Forestry, General Directorate of Forests, Ankara. $160 \mathrm{p}$.

Barbosa, R. I. and P. M. Fearnside (2004): Wood density of trees in open savannas of the Brazilian Amazon. Forest Ecology and Management 199: 115-23.

FALCONER, D. S. and T. F. C. MACKAY (1996): Introduction to quantitative genetics. $4^{\text {th }}$ ed. Longman. Essex, England. $463 p$.

FALCONER, D. S. (1981): Introduction to quantitative genetics. $2^{\text {nd }}$ ed. Longman, New York, 335 p.

Fischer, R., G. Becher, M. Lorenz, M. KöHL, G. Oliver and C. Andreas (2008): Special Focus: Brutia pine forests in the Mediterranean basin, pp. 23-24. In: The Condition of Forests in Europe: Executive Report, edited by United Nations Economic Commission for Europe (UNECE), Hamburg.

FRIES, A. and T. ERICSON (2006): Estimating genetic parameters for wood density of Scots Pine (Pinus sylvestris L.), Silvae Genetica 55(2): 84-92.

Fries, A. and T. ERICSON (2009): Genetic parameters for earlywood and latewood densities and development with increasing age in Scots pine. Annals of Forest Science 66(4): 1-8.

GEZER, A. (1986): The silviculture of Pinus brutia Ten. in Turkey. Options Méditerranéennes 86/1(5): 55-66.

GEZER, A. and S. AsLAN (1980): Studies on the selection of some best growing coniferous tree species in the southeastern Anatolia. The Republic of Turkey-The Ministry of Envriornment and Forestry, General Directorate of Forests, Technical Bulletin No: 103, Ankara, 42 s.

GöKSEL, E. and Ö. ÖzDEN (1993): Turkish Red Pine in pulp and paper industry, pp: 648-654. In: International Pinus brutia symposium. Edited by N. ÇEPEL, M. BoYDAK, O. TAŞKIN, Marmaris, Turkey.

GRAY, J. (1965): Extraction techniques, pp. 530-587. In: Handbook of paleontological techniques Edited by B. Kummel and D. M. RauP, W. H. Freeman. San Francisco.

GULLER, B. (2007): The effects of thinning treatments on density, MOE, MOR and maximum crushing strength of Pinus brutia Ten. wood. Annals of Forest Science 64: 467-475.

GÜRBOY, B. (2007): Fiber morphology of Calabrian pine (Pinus brutia Ten.) naturally grown in north Cyprus. Süleyman Demirel Üniversitesi Orman Fakültesi Dergisi Seri: A (2): 119-127.

HANNRUP, B. and I. EKBERG (1998): Age-age correlations for tracheid length and wood density in Pinus sylvestris. Canadian Journal of Forest Research 28: 1373-1379.

HANnRup, B., Ö. DANELl, I. EkBERG and M. Moell (2001): Relationship between wood density and tracheid dimensions in Pinus sylvestiris L. Wood Fiber Science 3: 178-185.

Hodge, G. R. and R. C. PuRnel (1993): Genetic parameter estimates for wood density, transition age, and radial growth in slash pine. Canadian Journal of Forest Research 23: 1881-1891.

Hollowell, R. R. and R. L. Porterfield (1986): Is tree improvement a good investment? Journal of Forestry 84(2): 46-48.

ICGen, Y., Z. KAYA, B. ÇENGel, E. VelioĞLU, H. ÖZtürK and S. ÖNDE (2006): Potential impact of forest management and tree improvement on genetic diversity of Turkish red pine (Pinus brutia Ten.) plantations in Turkey. Forest Ecology and Management 225(1-3): 328-336.

IşIK, K. and N. KARA (1997): Altitudinal variation in Pinus brutia Ten, and its implication for genetic conservation and seed transfer in Southern Turkey. Silvae Genetica 46(2-3): 113-119.

IşıK, F. and K. IşıK (1999): Genetic variation in Pinus brutia Ten, in Turkey (II): Branching and crown traits, Silvae Genetica 48(6): 293-301.

JaYAickKRAMA, K. J. S., S. E. MCKeAND, J. B. Jett and E. A. WHEELER (1997): Date of early-latewood transition in provenances and families of loblolly pine, and its relationship to growth phenology and juvenile wood specific gravity. Canadian Journal of Forest Research 27: 1245-1253. 
KAYA, Z., R. K. CAMPBELL and W. T. ADAMS (1989): Correlated responses of height increment and components of increment in 2-year old Douglas-fir. Canadian Journal of Forest Research 19: 124-1130.

KAYA, Z. and F. IşIK (1997): The pattern of genetic variation in shoot growth of Pinus brutia Ten, populations sampled from the Toros Mountains in Turkey. Silvae Genetica 46: 73-81.

Kaya, Z., F. Steel, A. Temerit and H. Vurdu (2003): Genetic variation in wood specific gravity of half-sib families of Pinus nigra subsp pallasiana: Implications for early selection. Silvae Genetica 52(3-4): 153-158.

KaYA, Z., K. YildiRIM, H. ÖZTÜRK, S. ŞIKLAR, M. Alan and E. ILTER (2008). Determination of inheritance and genetic gains in Turkish red pine wood quality characteristics (wood density, fiber characters, spring and summer wood ratios) in order to increase quality wood production in the Low Elevation Mediterranean Breeding zone. The Scientific and Technical Research Council of Turkey, Agriculture, Forestry and Veterinary Research Grant Committee, Project Final Report TOVAG-106O392, 78p.

Koch, L. and L. Fins (2000): Genetic variation in wood specific gravity from progeny tests of ponderosa pine (Pinus ponderosa Laws.) in northern Idaho and western Montana. Silvae Genetica 49: 174-181.

Koski, V. and J. ANTOLA (1993): Turkish national tree breeding and seed production program for Turkey (1994-2003), Cooperated with ENSO Forest Development Inc and Forest Tree Seeds and Tree Breeding Institute, Ankara, $49 \mathrm{pp}$.

KoGA, S. and S. Y. ZHANG (2004): Inter-tree and intra-tree variations in ring width and wood density components in balsam fir (Abies balsamea). Wood Science and Technology 38: 149-162.

LouzADA, J. L. P. C. and F. M. A. FonseCA (2002): The heritability of wood density components in Pinus pinaster Ait. and the implications for tree breeding. Annals of Forest Science 59: 867-873.

LYNCH, M. and B. WALsh (1998): Genetics and Analysis of Quantitative Traits. Sinauer Associates, Sunderland, MA, $990 \mathrm{p}$.

Nicholls, J. W. P., J. D. MorRis and L. A. Pederick (1980): Heritability estimates of density characteristics in juvenile Pinus radiata wood. Silvae Genetica 29: 54-61.

ÖZTÜRK, H., S. ŞIKLAR, M. Alan, T. Ezen, B. KorkMAZ, G. GÜlbaba, R. Sabuncu, M. Tulukcu and S. I. Derilgen (2004): Turkish Red Pine (Pinus brutia Ten.) progeny trials in low elevation breeding zone $(0-400 \mathrm{~m})$ of mediterranean region (fourth year results). Forest Tree Seeds and Tree Breeding Institute, Technical Bulletin No: 12, Ankara 147p.

ÖZTÜrk, H., S. ŞıKLAR, M. Alan, T. Ezen, B. Korkmaz, G. GÜlbaba, R. SABuncu, S. I. Derilgen and B. ÇAlişKAN (2008): Turkish Red Pine (Pinus brutia Ten.) progeny trials in low elevation breeding zone $(0-400 \mathrm{~m})$ of mediterranean region (eight-year results). Forest Tree Seeds and Tree Breeding Institute, Technical Bulletin No: 18, Ankara 122p.
Pot, D., C. Gulllaume, P. Rozenberg, J. C. Rodrigues, G. L. Jones, H. Pereira, B. Hannrup, C. Cahalan and C. PlOMION (2002): Genetic control of pulp and timber properties in maritime pine (Pinus pinaster Ait.). Annals of Forest Science 59: 563-575.

Raymond, C. A., R. Dickson, D. Rowell, P. Blakemore, N. Clark, M. Williams, G. Freischmidt and B. Joe (2004): Wood and fibre properties of dryland conifers. RIRDC Publication 99(4): 71.

SAS Institute Inc. (2004): SAS Online Doc 9.1.3. Cary, NC: SAS Institute Inc.

Schutz, W. M. and C. C. Cockerham (1966): The effect of field blocking on gain from selection. Biometrics 22(4): 843-863.

Shelbourne, C. J. A., L. A. Apiolaza, K. J. S. JaYAwickrama and C. T. SoRENSSON (1997): Developing breeding objectives for radiata pine in New Zealand, pp. 160-168. In: IUFRO'97 Genetics of Radiata Pine, edited by R. D. Burdon and J. M. Moore Rotorua, New Zealand.

SORENSEN, F. C. and T. L. White (1988): Effect of natural inbreeding on variance structure in tests of wind pollinated Douglas-fir progenies. Forest Science 34(1): 102-118.

Stener, L. and Ö. HedenberG (2003): Genetic parameters of wood, fibre, stem quality and growth traits in a clone test with Betula pendula. Scandinavian Journal of Forest Research 18: 103-110.

TAlBeRT, J. T., J. B. JetT and R. L. BRYANT (1983): Inheritance of wood specific gravity in an unimproved loblolly pine population: 20 years of results. Silvae Genetica 32: 33-37.

Usta, H. Z. (1991): Yield researches on Pinus brutia plantations (Kızılçam (Pinus brutia Ten) ağaçlandırmalarında hasılat araştırmaları). The Ministry of Forestry, Technical Bulletin No: 213, Ankara 138p.

Williamson, G. B. and M. C. WiEmanN (2010): Measuring wood specific gravity correctly. American Journal of Botany 97(3): 519-524.

YANCHUK, A. D. and G. K. KIss (1993): Genetic variation in growth and wood specific gravity and its utility in the improvement of Interior Spruce in British Colombia. Silvae Genetica 42(2-3): 141-148.

Zamudio, F., R. Baettyg, A. Vergara, F. Guerra and P. RozenBerg (2002): Genetic trends in wood density and radial growth with cambial age in a radiata pine progeny test. Annals of Forest Science 59: 541-549.

ZHANG, S. Y. and Z. H. JIANG (1998): Variability of selected wood characteristics in 40 half-sib families of black spruce (Picea mariana). Wood Science and Technology 32(1): 71-82.

ZoBel, B. J. and J. P. van BuiJTenen (1989): Wood Variation: Its causes and control. Springer, Berlin Heidelberg New York, 363p.

Zobel, B. J. and J. TALBERT (1984): Applied Forest Tree Improvement, John Wiley and Sons, New York, 511 p.

ZoBel, B. J. and J. B. JeTt (1995): Genetics of wood production. Springer-Verlag, New York, 337 p. 